\title{
ADMIRALTY BAY TROPHIC RELATIONSHIPS: A SUMMARY OF RESULTS FROM ISOTOPIC ANALYSIS
}

http://dx.doi.org/10.4322/apa.2014.014

\author{
Thaís Navajas Corbisier, Sandra Bromberg \& Mônica Angélica Varella Petti*
}

Instituto Oceanográfico, Universidade de São Paulo - USP, São Paulo - SP, Brazil *e-mail: tncorbis@usp.br

Information on marine trophic relationships is usually obtained from diet studies or analysis of carbon and nitrogen stable isotopes from organisms. The first trophic study with this kind of analysis in Admiralty Bay (Figure 1) was undertaken in front of the Brazilian Station "Comandante Ferraz" (CF) during the summer of 1996/97. The link between the various potential energy sources and the coastal shallow water community was evaluated using the carbon isotope ratio $\left(\delta^{13} \mathrm{C}\right)$. Three primary sources of organic matter have been identified: SPM (phytoplankton and suspended particulate matter); microphytobenthos; and macroalgae fragments. Higher values of $\delta^{13} \mathrm{C}$ are due to the carbon contribution of these fragments and of microphytobenthos (Corbisier et al., 2004).

There is a bentho-pelagic coupling between the plankton and suspension feeders such as the bivalve Laternula elliptica, the ophiuroid Ophionotus victoriae and the fish Chaenocephalus aceratus. Benthic grazers such as the gastropod Nacella concinna, deposit feeders such as the bivalve Yoldia eightsi and the nematodes show a close relationship with the microphytobenthos. Several deposit feeders and/or omnivores (polychaetes, amphipods, sea urchins, and holothurians) seem to have a mixed diet with macroalgae fragments and organic matter from the sediment, including microphytobenthos and/or meiofauna. Benthic carnivores and/or scavengers, such as the isopods Paraserolis polita and Glyptonotus antarcticus, the sea star Odontaster validus, the nemertean Parborlasia corrugatus and carnivorous polychaetes, generally show a considerable isotopic carbon ratio overlap throughout the food chain without any clear coupling with the primary sources of organic material. Their diet probably consists of a wide variety of prey.

In the summer of $2000 / 2001$, Bromberg (2004) compared the trophic web in front of Wanda Glacier (WG) and of CF, opposite sides in Martel inlet (Figure 1). The isotopic carbon ratios of the suspension feeders were similar. Some invertebrate grazers and deposit feeders presented higher ratios at CF than at WG, which was attributed to the hydrodynamic differences between the two sites, reflected in the $\mathrm{C}$ signature of the microphytobenthos. Further, the carnivore invertebrates, such as the nemertean $P$. corrugatus, which have a smaller range of prey available at WG, had lower $\delta^{13} \mathrm{C}$ values than at CF. The infaunal polychaetes and the amphipods were analyzed with more detail in this study. The polychaetes showed a high variation in the ratios, with values close to those of the macroalgae and nematodes (Levinsenia gracilis and some terebellids), and of the microphytobenthos (Rhodine antarctica and Ammotrypane sp). The most part of them presented ratios intermediate between these sources of food, suggesting a great diversity of food habits. Amphipods presented similar values, which also reflect a wide spectrum of feeding strategies.

The general comparison of the results in two summer periods at CF (1996/97 and 2000/01) showed higher ratios in 2000/01, which were more evident in the depositivores and necrophages/carnivores, suggesting a different contribution from some source of organic material (Bromberg, 2004).

In the summer of 2003, the sources of organic matter and their flow in the coastal benthic trophic web were examined, using isotope ratios of $\mathrm{C}$ and $\mathrm{N}$, at four different 


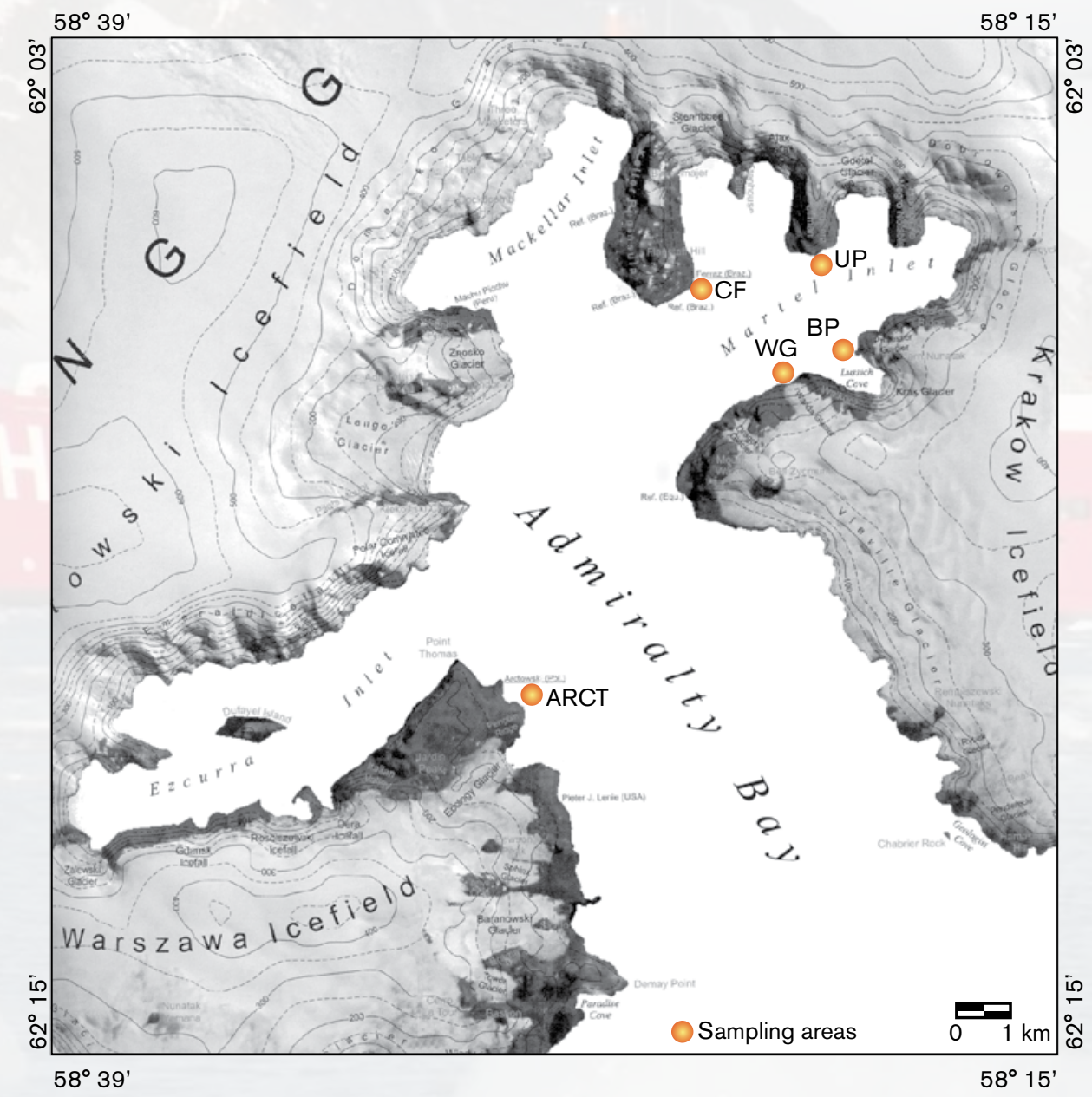

Figure 1. Admiralty Bay, King George Island. Sampling areas: ARCT - south to the Polish Station Henry Arctowski; CF - off Brazilian Antarctic Station Comandante Ferraz; UP - Ullmann Point; BP - Botany Point; WG - Wanda Glacier. Adapted from Braun et al. (2001).

sites from Admiralty Bay (Figure 1): in front of Ferraz Station (CF); at Botany Point (BP); at Ullman Point (UP); and south to the Polish Station "Arctowski" (ARCT). Major differences were found between the isotopic ratios from the components of the ARCT communities compared to those within Martel Inlet (Corbisier et al., unpublished results).

Near Arctowski Station the environment is more subject to high hydrodynamics, and also to outflows from the penguin colony in the central part of the bay. Thus, the shallow water benthic community does not depend on organic matter from the sediment, but rather on SPM and macroalgae, mainly Himantothallus grandifolius. The sediment at ARCT presented a very high $\delta^{15} \mathrm{~N}$ signature (15 and $18 \%$ ) clearly due to the presence of the penguin colonies which contribute with organic material through faeces. Mizutani and Wada (1988) reported high values of the isotopic signatures of $\mathrm{N}$ in guano and the soil of the penguin colony in Antarctica (13.4 to $31.8 \%$ ). The $\delta^{13} \mathrm{C}$ value of the sediment was low (about $-28 \%$ ), close to that of the SPM, possibly due to the local hydrodynamics. This signature may also be related to the organic contribution of the penguin colony (Mizutani \& Wada, 1988), with similar values to those obtained at ARCT. Conversely, in the three sites within Martel Inlet the sources of organic 
matter were highly linked to the microphytobenthos and sediment, as well as to the SPM and macroalgae.

Considering the four areas studied, $\delta^{15} \mathrm{~N}$ ranged from low values (-0.9 to $1.9 \%$ ) of SPM and macroalgae to 9.0 to $12.1 \%$ of benthic carnivores, showing around 3.5 to 4.5 steps in the trophic web. ARCT and BP presented a shorter benthic trophic web: $\delta^{15} \mathrm{~N}$ of consumers ranged from $2.8 \%$ (krill) to $10.8 \%$ (carnivore nemertean), at ARCT, and from $1.5 \%$ (ascidians) to $9.1 \%$ (carnivore polychaete), at BP. The $\delta^{15} \mathrm{~N}$ values of consumers ranged between $2.0 \%$ (ascidians) and 10.9\%o (a sea star) at UP and from $1.2 \%$ o (ascidian) to $12.1 \%$ (priapulan) at CF (Corbisier et al., unpublished results). The numbers of trophic levels are in accordance with the studies in the continental shelf of temperate, tropical and subtropical regions (Corbisier, 2006).

The trophic web at ARCT, a more dynamic area, and at $\mathrm{BP}$, under the influence of glaciers, had low diversity of food sources and are less complex than those at UP and CF where the diversity and quantity of organic matter were high, mainly from microphytobenthos (Skowronski \& Corbisier 2002; Bromberg, 2004; Skowronski et al. 2009). These communities were also more diverse regarding taxonomic groups.

In Admiralty Bay, the trophic chain in the shallow coastal zone, under the seasonal ice-cover and with benthic communities of high density and biomass, is more complex than in oceanic areas where the organic matter of pelagic origin is the main source of food.

Following a general monitoring program established for the next 5 years (INCT-APA), new results of stable isotopes are intended to be obtained in the summer of 2010/2011 in order to compare different periods and areas, aiming to verify the existence of some changes which could be attributed to anthropogenic activities, such as the influence of sewage. This kind of approach was used near the McMurdo Station, in Antarctica (Conlan et al., 2006).

\section{References}

BRAUN, M. et al. King George Island Satellite Map (1:100.000). 2001.

BROMBERG, S., 2004. A macrofauna bentônica da zona costeira rasa e o seu papel na trama trófica da enseada Martel, Baía do Almirantado (Ilha Rei George, Antártica). Ênfase para o grupo Polychaeta (Annelida). Dissertation - Instituto Oceanográfico, Universidade de São Paulo, São Paulo.

CONLAN, K. E.; RAU, G. H.; KVITEK, R. G. $\delta^{13} \mathrm{C}$ and $\delta^{15} \mathrm{~N}$ shifts in benthic invertebrates exposed to sewage from McMurdo Station, Antarctica. Marine Pollution Bulletin, v. 52, p. 1695-1707, 2006.

CORBISIER, T. N. Trofodinâmica do ecossistema bentônico de plataforma continental da costa sudeste do Brasil: Uso de isótopos estáveis de carbono e nitrogênio. Dissertation - Instituto Oceanográfico, Universidade de São Paulo, São Paulo, 2006.

CORBISIER, T. N. et al. Trophic relationships in the nearshore zone of Martel Inlet (King George Island, Antarctica): ${ }^{13} \mathrm{C}$ stable isotope analysis. Polar Biology, v. 27, p. 75-82, 2004.

MIZUTANI, H.; WADA, E. Nitrogen and carbon isotope ratios in seabird rookeries and their ecological implications. Ecology, v. 69, p. 340-349, 1988.

SKOWRONSKI, R. S. P.; CORBISIER, T. N. Meiofauna distribution in Martel Inlet, King George Island (Antarctica): Sediment features versus food availability. Polar Biology, v. 25, p. 126-134, 2002.

SKOWRONSKI, R. S. P. et al. Distribution of microphytobenthic biomass in Martel Inlet, King George Island (Antarctica). Polar Biology, v. 32, p. 839-851, 2009. 